Institute for Research on Poverty

Discussion Paper no. 1162-98

\title{
Black Applicants, Black Employees, and Urban Labor Market Policy
}

\author{
Harry J. Holzer \\ Department of Economics \\ Michigan State University \\ E-mail: holzer@pilot.msu.edu
}

May 1998

I am grateful to John Bound for helpful suggestions on estimation strategies in this paper and to Jess Reaser for excellent computational assistance.

IRP publications (discussion papers, special reports, and the newsletter Focus) are now available on the Internet. The IRP Web site can be accessed at the following address: http://www.ssc.wisc.edu/irp/ 


\begin{abstract}
In this paper, I use data from a new survey of employers in four large metropolitan areas to analyze the flow of black applicants to different kinds of employers and the extent to which these applicants are hired. The results show that less-educated black workers apply less frequently for jobs in the suburbs than in central cities, especially at smaller establishments. Their lower tendency to apply for suburban jobs is mostly accounted for by the higher costs to central-city black residents of applying there, and by lower information flows as well. Black applicants, especially less-educated black males, are also less likely to be hired at suburban establishments, particularly where they must deal with white customers. These results suggest the need for policies to reduce the costs of applying for suburban jobs and to improve the flow of information about suburban employment prospects to less-educated blacks, and perhaps a need to complement such policies with more effective enforcement of antidiscrimination laws in small suburban establishments.
\end{abstract}




\section{Black Applicants, Black Employees, and Urban Labor Market Policy}

\section{INTRODUCTION}

Recent evidence suggests that minorities are much more likely to be employed at some types of firms than others. For instance, federal contractors are more likely to employ minorities (and women) than are noncontractors (Leonard, 1990); larger firms are more likely to employ blacks than are small ones (Carrington, McCue, and Pierce, 1995; Chay, 1995; Holzer, 1996); and firms located near blacks in metropolitan areas or having more black customers are more likely to employ blacks than are those located farther away (Leonard, 1985; Holzer and Ihlanfeldt, 1996, forthcoming). The employment of blacks in manufacturing has declined dramatically in some areas (e.g., the Midwest) while that of Hispanics has risen (Bound and Holzer, 1993; Holzer, 1996). These factors reflect not only where blacks become employed but also their overall earnings and employment levels (as I discuss below).

These results raise the question of whether these differences reflect decisions made on the supply or the demand side of the labor market. On the supply side, blacks or Hispanics may choose to apply to different firms than whites do. This might be due to differences across these groups in the costs of applying to particular firms, perhaps associated with the locations of these firms or their recruitment activities. The perceived benefits of applying to different firms (in terms of compensation or the probabilities of being hired) might also vary across ethnic groups. Alternatively, firms may choose to hire blacks or Hispanics from among their applicants at higher or lower rates, depending on the relative skills of the applicants (i.e., relative to applicants from whites or other groups and relative to skill needs on jobs), discriminatory preferences among employers across different groups, etc.

Devising policy approaches to deal with these issues depends on separating those rooted in applicant behavior from those based on employer hiring. For instance, to the extent that a "spatial mismatch" between inner-city minority residents and suburban jobs plagues metropolitan labor markets 
(e.g., Kain, 1992), some policy recommendations emphasize job placement or transportation assistance (e.g., Hughes and Sternberg, 1992) while others emphasize residential desegregation and mobility (Rosenbaum and Popkin, 1991; Kain, 1992). Indeed, the ongoing demonstration projects known as "Bridges to Work" and "Moving to Opportunity" (both administered by the U.S. Department of Housing and Urban Development) are based on the two approaches, respectively. But both of these approaches assume that the employment and earnings of blacks will improve if their access to (or ability to apply for) suburban employment is raised. Alternatively, if employers in these areas refuse to hire black applicants, it may also take significant improvements in the enforcement of Equal Employment Opportunity (EEO) laws and/or skill enhancement to raise these employment rates.

Despite the importance of sorting out these sources of variance in black employment rates, little serious attention has been paid to this issue in the research literature. Part of the reason for this is the paucity of data on the demand side of the labor market in general, and on application rates across firms or economic sectors by race more specifically. In other cases, the relevance of where different groups apply for work has not even been recognized. For instance, the recent "audit studies" of employers (e.g., Fix and Struyk, 1994) implicitly control for differences in the numbers of applicants firms receive by sending matched pairs of black (or Hispanic) and white applicants to each firm (with both quantity and observable quality of applicants equalized across racial groups), which assumes that observed employment differences will be driven by demand-side choices exclusively. While this approach provides a clean test of labor market discrimination, it does not allow for the self-sorting of white and black applicants across different areas and sectors that clearly seems to occur in actual labor markets, with consequences for both the quantity and relative quality of applicants received by different kinds of employers.

In this paper, I analyze the extent to which different employers receive applications from blacks, as well as their different tendencies to hire blacks from their applicant pools. I use data from a new 
survey of employers in several large metropolitan areas for this analysis. The theoretical relationship between relative application and employment rates across groups is investigated in the next section, using a supply and demand framework. Data and specification issues are discussed in the third section.

Empirical results appear in the fourth section, and a summary and discussion of policy implications are presented in the final section.

\section{APPLICATIONS AND EMPLOYMENT RATES BY RACE: THE THEORY}

In this section, I present an informal discussion of the factors determining the application and employment rates of blacks across firms. The discussion is consistent with other, more formal, treatments in the literature of the search/application process across firms (e.g., Holzer, Katz, and Krueger, 1991; Lang and Dickens, 1993).

In Figure 1, I show the determinants of relative application rates from blacks to different firms. $\mathrm{E}(\mathrm{B})$ reflects the expected relative benefits that accrue to individual blacks from applying at firm 0 or 1 , while $\mathrm{C}$ represents the relative costs to them of doing so. The expected benefits are based on the probability that an applicant at any firm will be hired, and the relative wages, benefits, and working conditions that will accrue to the worker if this occurs. The costs of applying include both time and expenses of filing the application and going through the screening process.

The number of applicants at each firm is determined at the point where benefits equal costs for the "marginal" black applicant. For a given set of applicants, the average expected benefits they face at each firm are then determined. The expected benefits per black applicant at each firm should decline with rising numbers of applicants, as the likelihood that each applicant will be hired is reduced. The expected relative benefits will also vary across firms, depending on the skill needs of the employer, the degree to which the firms discriminate against blacks, or other institutional factors. For example, it appears that 
Figure 1

Expected Benefits and Costs Facing Black Applicants at Firms

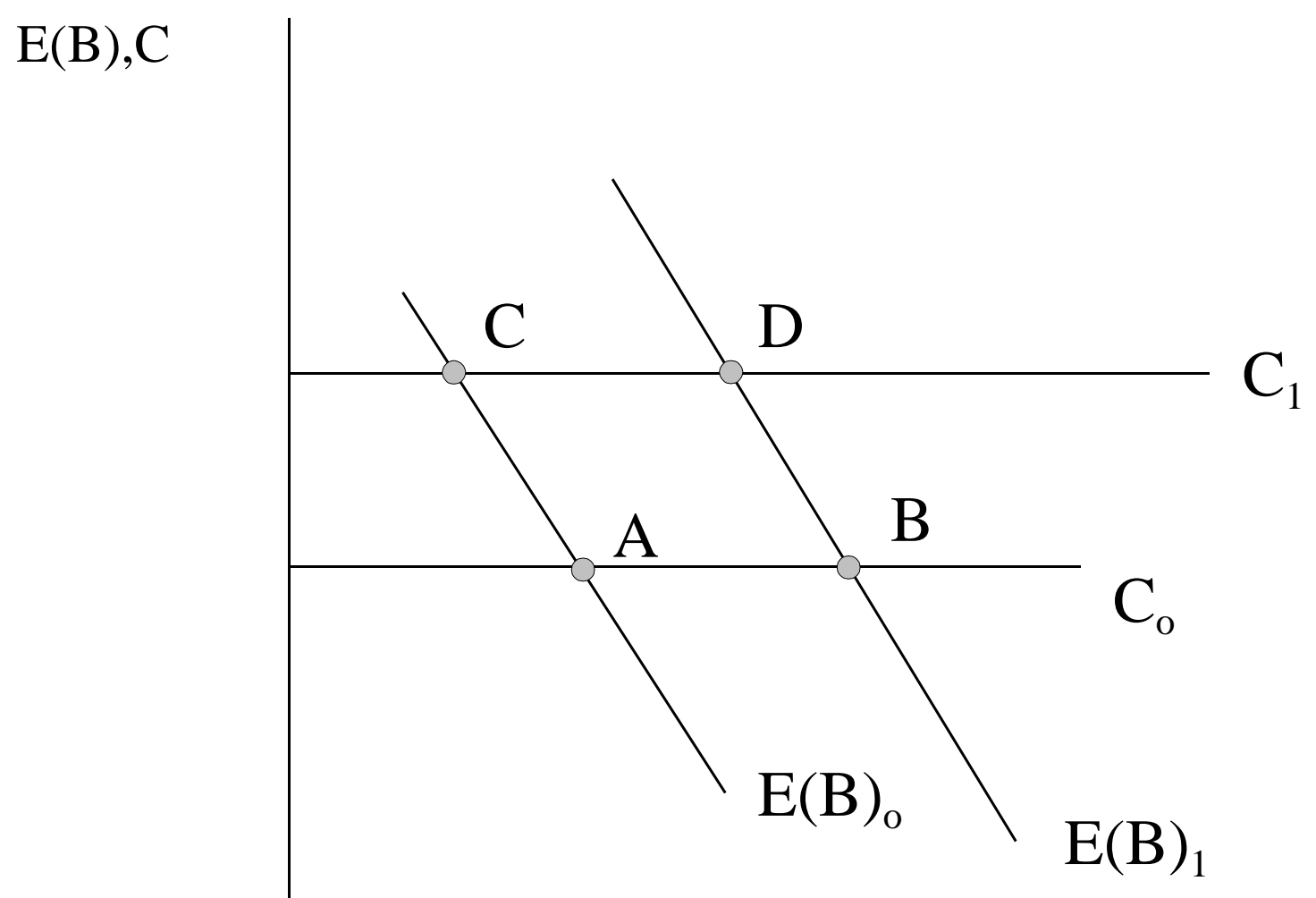

Blacks 
large firms, unionized firms, or those in manufacturing/utilities have traditionally employed relatively

more blacks than other kinds of firms and/or have paid them relatively well. ${ }^{1}$

The costs to individual blacks of applying for jobs also vary across the firms and depend on factors such as the location of the firm relative to the residential locations of blacks and other groups. Given the disproportionate residential concentration of blacks in central cities caused by housing segregation in metropolitan areas (e.g., Frey, 1995), it will generally be less costly for blacks to apply for jobs in firms located in or near these areas. ${ }^{2}$ The presence or absence of public transportation near these firms will also affect the relative cost of applications from blacks, especially among those who lack access to private automobile transportation (Holzer, Ihlanfeldt, and Sjoquist, 1994; Holzer and Ihlanfeldt, 1996).

The results of some simple "comparative statics" analysis are illustrated in Figure 1. For a given level of costs, firms with relatively high demand for black labor should attract more black applicants and hire more black employees, as seen when comparing points A and B. More applicants apply at the firm with higher relative demand until the probability that the marginal applicant is hired (and/or their relative wages) is equalized between firms, although the average applicant at the higher-demand firm still faces better opportunities. Thus, we should observe differences in employment rates out of the applicant pool

${ }^{1}$ For instance, Freeman and Medoff (1984) show that blacks are relatively more likely to gain unionized employment than whites and to earn higher relative wages in unionized establishments. Krueger and Summers (1987) show that less-skilled workers gain disproportionately higher wages in industries such as manufacturing and the utilities, and blacks have always been concentrated among the less-skilled group. Bound and Holzer (1993) show that blacks were heavily concentrated in manufacturing jobs in the Midwest as of 1970, though not so much in other regions. As noted above, the effects of firm size on relative black employment have been documented by Carrington et al. (1995), Chay (1995), and Holzer (1996).

${ }^{2} \mathrm{We}$ assume that the residential locations of white and black workers are given, as are the locations of firms. In the long run, the locations of each can vary and may well reflect the degree of access that each desires to have to the other. In other words, employers may locate in the suburbs at least partly to avoid receiving applications from blacks (Bloch, 1994), while blacks (as well as whites) may locate their residences in the suburbs, depending on their desires for access to suburban housing and neighborhood amenities as well as for access to employers located there (Mieszkowski and Mills, 1993). But the ability of blacks to reside in the suburbs will be limited not only by their incomes but also by housing market discrimination (Yinger, 1995). 
of blacks across these firms (or in their relative earnings), though the observed differences will be reduced somewhat by the higher application rates at firms where relative demand is higher.

Comparing points $\mathrm{A}$ and $\mathrm{C}$ (or B and $\mathrm{D}$ ), we find that firms at which it is relatively more costly for blacks to apply (e.g., those located in the suburbs that are far from residential locations of blacks or from public transit) should receive fewer black applicants and hire fewer black employees than those at which it is cheaper to apply (e.g., those located in central cities, especially near to black residential areas or public transit). But, in equilibrium, the expected benefits for the marginal applicant must equal the costs at each firm, implying that we should observe few black applicants but high employment probabilities (and/or relative wages) for those who do apply at high-cost firms.

Furthermore, if the costs and expected benefits to black applicants are positively correlated across firms (e.g., comparing points A and D in Figure 1), the gaps in employment across firms will be far greater than if the correlation is negative (points B and C). For instance, if firms located in the central city have lower skill requirements or lower tastes for discrimination, the gaps in employment of blacks between central-city and suburban employers will be greater than otherwise. ${ }^{3}$

This simple model can be modified or extended in a number of ways to incorporate a number of important characteristics of urban labor markets. For instance, the actual expected benefits to blacks of applying to any given firm may differ from those perceived by them if they have imperfect information about employment opportunities in the relevant labor market. The quality of information about employment opportunities may depend on the strength of social employment networks (e.g., Holzer, 1987) or on the recruitment activities of the firms themselves. Firms engaging in affirmative action (whether because they are federal contractors or because they choose to do so) may also disseminate information more broadly in the black community than they otherwise would, and employment

\footnotetext{
${ }^{3}$ We would expect this if, for instance, more discriminatory employers choose to locate in the suburbs, as Bloch (1994) argues.
} 
opportunities among firms located farther from black residences may be less well known if racial/ethnic employment networks are at least partly based on neighborhood of residence (e.g., Case and Katz, 1991; Borjas, 1992). In any event, application and employment rates of blacks will clearly be lower at firms if blacks perceive that the benefits to applying there are lower than they actually are.

Another important extension derives from the fact that black workers are heterogeneous in terms of skills, residential location, and so forth. Thus, the expected benefits and costs of applying to the same firm will differ among them. For instance, relatively more-educated blacks likely have lower transportation costs to many suburban firms because they are more likely than less-educated blacks to live in the suburbs and/or own automobiles. ${ }^{4}$ They may perceive greater expected benefits to applying to various firms (especially in the suburbs) due to better information about job opportunities. Also, the expected benefits they face may actually be higher as well, due to the greater relative employment probabilities when they apply or relative compensation when they are hired for these jobs.

The self-selection process described above implies that the average quality, as well as quantity, of black applicants may differ across firms. Furthermore, the quantity and quality of black applicants may be inversely related when comparing firms across geographic areas. Thus, the average quality of black applicants will be greater at firms located farther from black residential areas, implying that black applicants should be relatively more likely to be hired at these locations, all else being equal.

Also, differences in the quantity or quality of applications received from blacks across firms might well exist by gender, and they might differ between blacks and other disadvantaged minorities such as Hispanics. Gender differences continue to exist in the distribution of employment across occupations (e.g., Fuchs, 1989) that clearly reflect some combination of employee and employer preferences, but gender differentials appear to interact with race as well in many analyses of occupational, employment,

${ }^{4}$ For evidence that commute times or distances are correlated with education or automobile ownership, see Holzer et al. (1994) and Zax (1991). 
or earnings differences (e.g., Tigges, Browne, and Press, 1997). Gender differences exist within each racial group in the tendency of workers to search for and commute to work (Zax, 1991). Qualitative evidence of differences in employer preferences between black males and females has also been growing (Kirschenman, 1991). All of these factors suggest that differences in the fraction of applications received by firms from black males versus black females, as well as differences in hiring probabilities, might be found even after controlling for occupation, location, and other characteristics of jobs and establishments.

Comparing blacks with Hispanics, we find relatively lower residential segregation but also lower educational attainment and test scores among the latter (Frey, 1995; Hauser and Phang, 1993). Blacks and Hispanics also might experience different social networks and employer preferences in the labor market (especially when comparing immigrants and the native-born, as in Waldinger, 1996, or Falcon and Melendez, 1997). These should all contribute to differences between them in patterns of application and employment rates across firms.

Finally, how will the various differences in application and employment rates across firms contribute to differences in observed employment outcomes across these groups? At a minimum, these factors should generate some employment segregation by race/ethnicity and gender across firms (Carrington and Troske, 1998). But the extent to which such segregation results in lower wages and/or employment for blacks (or Hispanics) then depends on the relative wages, skill requirements, and job availability among those firms and areas to which each group has relatively greater access. If, for example, firms are relocating away from predominantly black areas more rapidly than is the local population, or if the firms remaining there pay lower wages (perhaps because of a "crowding" of blacks into those jobs, or other differences in product markets, technology, etc.), then the evidence would suggest that "spatial mismatch" is contributing to lower relative wages and/or employment among blacks. 


\section{DATA AND ESTIMATION ISSUES}

The data used here are from a survey of 3,200 employers in four major metropolitan areas:

Atlanta, Boston, Detroit, and Los Angeles. They were collected in telephone interviews between June 1992 and May 1994 with the individual at each establishment who was responsible for new hiring into noncollege positions (or certain specific occupations). ${ }^{5}$

Respondents were asked a wide range of questions about the overall establishment and the last job filled there, as well as the last worker hired into that job. Since establishments were drawn to generate a sample that was weighted ex ante by establishment size, a sample of the most recently filled jobs at these establishments constitutes a relatively representative sample of new jobs being filled in the labor force. ${ }^{6}$

We first present some summary statistics below on the percentages of applicants who are black at each establishment, the percentages of new hires who are black, and the ratio of the latter to the former. This ratio represents the conditional demand for any group of black applicants, based on their characteristics. These data are presented overall and by the educational requirements and occupational category of the job, as well as by industry and size of the establishment.

We then present estimated equations of the following form:

$$
\begin{gathered}
\text { RApps }_{j k}=a+b X_{k}+c X_{j}+e_{j k} \\
R_{j k}=d+e X_{k}+f X_{j}+n_{j k}
\end{gathered}
$$

${ }^{5}$ The methods by which the sample was drawn, and a variety of relevant issues related to response rates and selection, are discussed at length in Holzer (1996). Since the sample drawn is effectively weighted by size, we can consider each firm as an observation without further size-weighting. On the other hand, some sample-weighting is necessary for estimates to be based on representative samples, to adjust for the overrepresentation in the data of noncollege jobs and jobs filled by members of black households.

${ }^{6}$ Since the sample of establishments is roughly weighted by current employment size, it does not give additional weight to firms that do considerable hiring due to high turnover rates or net employment growth. Highturnover or high-growth job categories within establishments receive somewhat greater weight in this sample, though the occupational distributions here are quite similar to those that appear in the 1990 census for all employees in these metropolitan areas. 
where $\mathrm{R}$ represents whether the last worker hired is black, RApps represents the percentage of applicants who are black, $\mathrm{j}$ and $\mathrm{k}$ denote job and establishment respectively, and $\mathrm{X}$ includes control variables. $\mathrm{X}_{\mathrm{k}}$ includes variables for geographic location of the establishment-i.e., Metropolitan Statistical Area (MSA) dummies, whether it is located in the central city, its relative distance from white and minority populations, and whether it is located near (i.e., within one-quarter mile) a public transit stop—and controls for 1-digit industry, establishment size, and the presence of collective bargaining. $X_{\mathrm{j}}$ includes controls for various hiring requirements and tasks performed daily on the job. ${ }^{7}$

These equations are reduced forms to explain the demographic composition of applicants and the relative demand for these applicants, conditional on their characteristics. The $\mathrm{X}_{\mathrm{j}}$ and $\mathrm{X}_{\mathrm{k}}$ variables have been chosen to reflect the likely determinants of relative application costs and relative expected benefits, where the latter determine employment as well. For instance, occupation differences reflect skill requirements that should influence hiring probabilities across the two groups; industry, establishment size, and presence of collective bargaining affect relative hiring probabilities (either perceived or actual), as noted above; geographic variables reflect the relative costs to blacks of applying for jobs; and other variables, such as use of affirmative action and/or recruitment methods, likely reflect preferences or information flows across groups.

Since the racial composition of a firm's applicants directly affects the race of those persons it hires, RApps might have been included among the determinants of R in equation (2). However, the application rate is no doubt measured with some error by respondents to the survey, which is likely to generate a downward bias in estimated coefficients on that variable. Furthermore, the theory above suggests that the application rate from blacks should respond to the likelihood that blacks will be hired at

\footnotetext{
${ }^{7}$ The hiring requirement variables are dummies for whether each of the following is absolutely necessary or strongly preferred: college or high school diplomas, specific experience, previous training, and references. The task variables are whether each of the following must be performed on a daily basis: direct contact with customers (in person or on the phone), reading/writing of paragraph-length material, arithmetic, and use of a computer.
} 
any firm, thereby making this applicant rate endogenous with respect to observed employment outcomes. Because of these problems, I choose instead to estimate reduced-form versions of both equations.

Then, to infer the effect of any given characteristic of jobs or establishments on the probability of being hired among blacks who apply for specific jobs, I calculate ratios of predicted values of black new hires to applicants, based on estimated coefficients from equations (1) and (2). In generating these predicted values, all independent variables are assigned their mean values except for the particular characteristic in question. These calculations are described in more detail below.

But, when considering either the summary data or the equations, some caveats must be noted. For one thing, the endogeneity of black application rates with respect to employment probabilities should bias the ratios of coefficients or predicted values to one, thus understating differences across firms in the conditional demand for blacks. Where such differences are observed, they can be interpreted as lower bounds to the true differences in relative demand. As noted above, employment probabilities at firms where the costs to blacks of applying are high will also appear quite high (because these firms receive so few applicants), thereby generating overestimates of demand for black applicants at such firms.

Furthermore, the relative quantities of black applicants at each firm are observable but their relative qualities are not. If black applicants of varying qualities self-select into different firms, the same hiring behavior (conditional on particular characteristics of applicants) across these firms may generate differences in observed conditional hiring rates. However, where estimated differences in conditional hiring rates can be observed that go in the opposite direction from those predicted by the relative quality of the black applicant pool, we can infer differences in relative demand for black labor across establishments that might well be attributable to differences in employer preferences for black labor. 


\section{RESULTS}

\section{A. Summary Statistics}

In Table 1 I present summary data on the percentage of applicants and new hires at establishments who are white, black, and Hispanic. These appear separately for males and females among blacks, and for establishments located in the central-city and suburban sections of their respective metropolitan areas. ${ }^{8}$ In addition to the percentages of applicants and new hires who are black, I also present the ratio of new hires to applicants for each group, as a measure of labor market demand for these applicants (conditional on their characteristics and those of the jobs to which they are applying). ${ }^{9}$ Ratios less than 1 for any group indicate a relative disinclination among employers to hire applicants from that group, while ratios greater than 1 indicate a relative inclination to hire from the group. ${ }^{10}$ All means are sample-weighted.

The results show that blacks and Hispanics together account for roughly 43 percent of applicants and 32 percent of new hires in these four metropolitan areas. The incidence of Hispanic applicants and new hires is overwhelmingly concentrated in Los Angeles (and, to a much lesser extent, in Boston). The new hire rates are roughly proportional to the fractions of blacks and Hispanics in the relevant local populations, while the application rates exceed these ratios. This is to be expected, since blacks and Hispanics should be more heavily concentrated among job seekers than in the population or labor force more generally and because of their higher rates of unemployment.

\footnotetext{
${ }^{8}$ Application rates were gauged in the survey only for black males, black females, Hispanics, and Asians. The latter group is implicitly included along with whites in all calculations here.

${ }^{9}$ The ratios presented in Table 1 represent the ratios of means of new hires to applicants, rather than means of ratios defined at the individual level. Since only one new hire is described in the data for each establishment, it would be impossible to define such a ratio at the establishment level.

${ }^{10}$ Weighted averages of these ratios across groups, weighted by the percentages of applicants accounted for by each group, should sum to 1 .
} 


\section{TABLE 1}

Mean Application and New Hires Rates: By Race, Gender, and/or Location

\begin{tabular}{|c|c|c|c|c|c|c|c|c|c|}
\hline & \multicolumn{3}{|c|}{ Total } & \multicolumn{3}{|c|}{ Central City } & \multicolumn{3}{|c|}{ Suburbs } \\
\hline & Apps & $\mathrm{NH}$ & Ratio & Apps & $\mathrm{NH}$ & Ratio & Apps & $\mathrm{NH}$ & Ratio \\
\hline Whites & .573 & .683 & 1.192 & .428 & .559 & 1.306 & .651 & .762 & 1.171 \\
\hline Blacks & .274 & .173 & .631 & .389 & .269 & .692 & .206 & .112 & .543 \\
\hline Males & .149 & .085 & .570 & .208 & .130 & .625 & .115 & .055 & .478 \\
\hline Females & .125 & .089 & .712 & .181 & .139 & .768 & .091 & .057 & .626 \\
\hline Hispanics & .153 & .144 & .941 & .183 & .172 & .940 & .143 & .126 & .881 \\
\hline
\end{tabular}

Note: Asians are included in the sample of "whites" above. All means are sample-weighted. "Apps" and "NH" represent the percentages of applicants and new hires accounted for by each group, while "Ratio" represents the ratio of the latter to the former. 
Some distinct patterns can also be found in the ethnic composition of applicants across geographic areas. For instance, the share of black applicants is almost twice as large in central cities as in suburban areas, which parallels the relative residential concentrations of blacks in these areas. Hispanics also account for greater percentages of applicants in central cities, though the geographic differences are less than for blacks. ${ }^{11}$ Thus, where people seek employment is clearly influenced by where they live, perhaps because of costs associated with long-distance searching or commuting, or because of limited information about employment prospects at more distant locations, or even because of perceived hostility in areas where few residents of one's own group reside.

The ratios of new hires to applicants also show several distinct patterns: (1) These ratios are highest for white applicants and lowest for blacks in all locations; (2) they are higher for black females than for black males in all locations; and (3) they are higher in central cities than in the suburbs for both black males and black females.

These findings are discussed at greater length elsewhere (Holzer, 1996, forthcoming). Because the hiring rates for any group are conditional on characteristics of the relevant applicant pool, they could reflect differences in the process of self-selection (or matching) of applicants to employers. Thus, if whites or Hispanics have better employment networks than blacks, providing them with better information about where to apply, the ratios of hires to applicants observed among whites or Hispanics would be higher.

Alternatively, differences in these ratios could reflect differences in employer perceptions of the relevant ethnic populations, which might reflect real differences in skills across these groups or discriminatory attitudes among employers. On average, skill levels (as measured by educational attainment or test scores) are higher among whites than minorities but are generally lower among

\footnotetext{
${ }^{11}$ This is, to some extent, accounted for by the fact that central-city versus suburban differences in Los Angeles (where most of the Hispanics in the sample are found) are less pronounced than in other metropolitan areas in terms of where different ethnic groups live and work.
} 
Hispanics than blacks (Mare, 1995; Hauser and Phang, 1993). In fact, the higher ratios for Hispanics than blacks and for black females than black males are consistent with qualitative evidence on employer preferences across these groups (Waldinger, 1996; Kirschenman and Neckerman, 1991; Kirschenman, 1991). This ethnographic evidence suggests that employers often prefer other ethnic groups (especially immigrants) to native-born blacks, since they perceive better attitudes and work ethic among the former and generally fear young black men more than their female counterparts.

The higher ratios of new hires to applicants among blacks in the central city than in the suburbs are also unlikely to reflect differences in relative applicant skills, since these are likely higher for blacks in the suburbs than in the central city. ${ }^{12}$ Furthermore, the ratios in the suburbs are more likely to be upward biased, as the higher costs that blacks incur (on average) when applying to jobs there generate fewer applicants who presumably face higher employer probabilities in equilibrium. The lower tendency of suburban employers to hire black applicants might therefore reflect more discriminatory attitudes toward blacks there, perhaps because of a propensity of discriminatory employers to locate in suburban areas (Bloch, 1994), or an actual causal effect of central-city location on employer behavior (as more direct contact with minorities or greater scrutiny of their behavior leads employers there to be less discriminatory). ${ }^{13}$

Overall, the data summarized in Table 1 suggest strong differences across geographic areas in the costs of applying for employment among blacks and Hispanics, as well as strong differences in the conditional demand for these applicants, relative to whites and to each other, that are also partly based on the geographic location of establishments.

\footnotetext{
${ }^{12}$ Educational levels are higher among blacks living in the suburbs than those in the central city, while the opposite is generally true among whites (Holzer, 1996). Wider geographic search patterns are also found among more educated employees, as discussed by Holzer et al. (1994).

${ }^{13}$ Raphael, Stoll, and Holzer (1998) show that even when the individuals in charge of hiring in the suburbs are black, they are still less likely to hire black applicants than are comparable central-city employers. Whether this reflects discrimination on the part of black suburban managers as well (who perhaps have incorporated the perceptions of their white neighbors and supervisors) is difficult to infer from the data.
} 
Additional summary results appear in Table 2, where I present the percentages of applicants from different race/gender groups by a variety of job/establishment characteristics, such as educational requirements or occupational category of the job, industry, and establishment size. Part A of the table presents these results for black and Hispanic applicants, while part B of the table presents results for black males and black females.

A number of important results appear in part A of Table 2. Jobs located in central cities attract many more black applicants if the jobs have lower educational requirements and are not in professional/managerial occupations. On the other hand, this is much less true in the suburbs. Put another way, the ratio of black applicants for jobs requiring high school or less to jobs requiring college is much lower than in central cities. Data by occupation tell a similar story—namely, blue-collar and service occupations in the suburbs draw relatively fewer black applicants than do white-collar jobs.

By industry, we find that construction and public sector establishments in the suburbs draw the fewest black applicants (relative to what they draw in central cities) and that suburban establishments in manufacturing, retail trade, and service industries also attract relatively fewer black applicants than those in the utilities and wholesale trade. ${ }^{14}$ And, while small establishments in both locations draw fewer black applicants than medium-sized and large establishments (where the three categories are defined as 1-50, 51-100, and 101 or more employees), the gap between black applicants at large versus medium-sized and small establishments is particularly large in the suburbs.

Taken together, these results suggest that less-educated blacks are much less likely to apply for suburban jobs, especially at small and medium-sized establishments, for which they may be well qualified. The results are consistent with the prediction based on the theory outlined above-namely that the high costs of applying for jobs in the suburbs for blacks residing in the central city leads to a self-

\footnotetext{
${ }^{14}$ Unfortunately, the small sizes of samples of establishments in construction and the public sector limit our ability to draw strong inferences about hiring patterns in these sectors.
} 
TABLE 2

Mean Application Rates and Ratio of New Hires to Applicants: By Job and Firm Characteristics

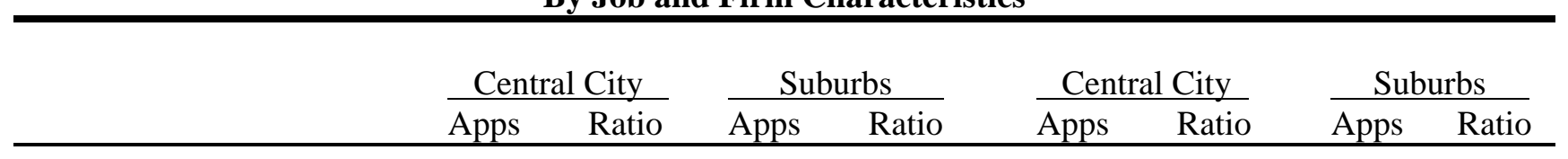

A.

\section{Educational Requirements}

College degree
High school diploma

No requirement

\section{Occupations}

Managerial/professional

Clerical/sales

Crafts

Operative/labor

Service

\section{Industries}

Construction

Manufacturing

TCU

Wholesale trade

Retail trade

FIRE/services

Public

\section{Employees \\ $1-50$ \\ $51-100$ \\ $>100$}

Blacks

\begin{tabular}{|c|c|c|c|c|c|c|c|}
\hline .240 & .492 & .173 & .266 & .262 & .691 & .110 & .482 \\
\hline $.42^{\prime}$ & .698 & .216 & .574 & .131 & 1.023 & .138 & .928 \\
\hline 4 & .793 & .213 & .728 & .256 & 1.164 & .192 & 1.07 \\
\hline
\end{tabular}

.293

$\begin{array}{llll}377 & 719 & .181 & .436 \\ & .216 & .472\end{array}$

.472

$\begin{array}{llll}.350 & .806 & .126 & .857\end{array}$

$\begin{array}{llll}.466 & .790 & .228 & .741\end{array}$

.621

.928

.253

.613

$\begin{array}{llll}.528^{\mathrm{a}} & .326^{\mathrm{a}} & .170 & .618 \\ .331 & .577 & .173 & .613 \\ .365 & .803 & .312 & .769 \\ .330 & .533 & .242 & .343 \\ .575 & .767 & .256 & .625 \\ .366 & .667 & .190 & .437 \\ .594^{\mathrm{a}} & .902^{\mathrm{a}} & .152^{\mathrm{a}} & 1.211^{\mathrm{a}}\end{array}$

$.594^{\mathrm{a}}$

$.902^{\mathrm{a}}$

$\begin{array}{llll}.380 & .639 & .178 & .449 \\ .486 & .669 & .194 & .959 \\ .378 & .751 & .261 & .513\end{array}$

.130
.191
.271

$.056^{\mathrm{a}}$
.319
.105
.189
.114
.195
$.059^{\mathrm{a}}$

$.000^{\mathrm{a}}$

.931

.552

$$
.794
$$

1.316

.949

$.000^{\mathrm{a}}$

.092

.139

.203

.211

.137

.609

.799

.936

1.047

1.299

$.059^{\mathrm{a}}$

$.000^{a}$

$.125 \quad .648$

$.234 \quad .722$

$.082 \quad .598$

$.166 \quad .922$

$.119 \quad .866$

$.115 \quad 1.052$

$.060^{\mathrm{a}} \quad 4.300^{\mathrm{a}}$

(table continues) 
TABLE 2, continued

\begin{tabular}{|c|c|c|c|c|c|c|c|c|}
\hline & \multicolumn{2}{|c|}{ Central City } & \multicolumn{2}{|c|}{ Suburbs } & \multicolumn{2}{|c|}{ Central City } & \multicolumn{2}{|c|}{ Suburbs } \\
\hline & Apps & Ratio & Apps & Ratio & Apps & Ratio & Apps & Ratio \\
\hline B. & \multicolumn{4}{|c|}{ Black Males } & \multicolumn{4}{|c|}{ Black Females } \\
\hline \multicolumn{9}{|l|}{ Educational Requirements } \\
\hline College degree & .096 & .740 & .091 & .319 & .144 & .326 & .082 & .207 \\
\hline High school diploma & .235 & .506 & .119 & .445 & .192 & .932 & .097 & .732 \\
\hline No requirement & .282 & .851 & .132 & .674 & .196 & .709 & .081 & .815 \\
\hline \multicolumn{9}{|l|}{ Occupations } \\
\hline Managerial/professional & .118 & .517 & .084 & .452 & .175 & .314 & .097 & .423 \\
\hline Clerical/sales & .194 & .490 & .116 & .224 & .183 & .962 & .100 & .760 \\
\hline Crafts & .235 & .745 & .099 & .848 & .115 & .930 & .027 & .889 \\
\hline Operative/labor & .377 & .804 & .158 & .854 & .089 & .730 & .070 & .486 \\
\hline Service & .321 & .907 & .138 & .565 & .300 & .950 & .115 & .661 \\
\hline \multicolumn{9}{|l|}{ Industries } \\
\hline Construction & $.424^{\mathrm{a}}$ & $.406^{\mathrm{a}}$ & .158 & .665 & $.104^{\mathrm{a}}$ & $.000^{\mathrm{a}}$ & .012 & .000 \\
\hline Manufacturing & .219 & .553 & .105 & .610 & .112 & .625 & .068 & .618 \\
\hline TCU & .251 & .952 & .205 & .702 & .114 & .482 & .107 & .897 \\
\hline Wholesale trade & .253 & .490 & .149 & .315 & .077 & .662 & .093 & .387 \\
\hline Retail trade & .330 & .788 & .147 & .463 & .245 & .739 & .109 & .844 \\
\hline FIRE/services & .163 & .521 & .094 & .372 & .203 & .783 & .096 & .490 \\
\hline Public & $.374^{\mathrm{a}}$ & $.701^{\mathrm{a}}$ & $.087^{\mathrm{a}}$ & $.414^{a}$ & $.220^{\mathrm{a}}$ & $1.241^{\mathrm{a}}$ & $.065^{\mathrm{a}}$ & $2.277^{\mathrm{a}}$ \\
\hline \multicolumn{9}{|l|}{ Employees } \\
\hline $1-50$ & .212 & .538 & .105 & .381 & .168 & .768 & .073 & .548 \\
\hline $51-100$ & .271 & .716 & .109 & .716 & .215 & .609 & .085 & 1.271 \\
\hline$>100$ & .190 & .689 & .138 & .529 & .188 & .814 & .123 & .496 \\
\hline
\end{tabular}

${ }^{\text {a }}$ Based on fewer than 20 observations. 
selection process in which the relatively more-skilled black workers apply to jobs in the suburbs more frequently, while unskilled blacks apply overwhelmingly to jobs in the central city that do not require high skills. Furthermore, highly skilled workers generally have more information about job opportunities over a wider geographic range than do less-skilled workers, which might lead the former to search over a wider range (Bound and Holzer, 1996; Ihlanfeldt, 1997, forthcoming). These results are also consistent with evidence from household surveys indicating that more-educated blacks may search over a wider geographic range than less-educated blacks, especially in the suburbs (Farley, Holzer, and Danziger, 1998).

The greater differences in application rates from blacks across industries and firm size categories in the suburbs than in central cities also suggest that, to receive many applications from black workers, the suburban establishments must be unusually salient or generate higher expected returns to search. Since large establishments are generally better known, pay higher wages, and seem to discriminate less than smaller establishments, it is not surprising that the former will attract more black applicants, especially in the suburbs where application costs are high for blacks. Similar arguments can be made as well for the utilities and wholesale trade relative to other sectors in the suburbs.

The pattern of where Hispanics apply for work differs somewhat from that observed among blacks. In particular, smaller suburban establishments attract many Hispanic applicants, and those in construction, the public sector, and retail trade draw many as well (relative to the service sector). By education and occupation, it is professional/managerial jobs in the suburbs and/or those that require high school degrees that draw relatively few Hispanic applicants. These results are, however, at least partly attributable to the fact that Hispanics are much more heavily concentrated in Los Angeles and Boston than are blacks. ${ }^{15}$ Applicant patterns by gender differ somewhat among blacks as well, with more-

\footnotetext{
${ }^{15}$ When these computations are limited to establishments in Los Angeles for both blacks and Hispanics, blacks also show a relatively greater tendency to apply to suburban establishments than they do in the other metropolitan areas.
} 
educated black males being relatively more likely to apply for suburban jobs than their female counterparts.

The ratios of new hires to applicants by race and/or gender also show some noteworthy results. In general, blacks are less likely to be hired in many sectors where they apply less frequently-e.g., in jobs requiring college, in professional/managerial occupations, and in smaller and/or suburban establishments. As suggested by the theory outlined above, black applicants are choosing to apply for work where their chances of being hired are greater, which certainly indicates some rationality in the self-selection process. As noted earlier, this implies that differences across groups in conditional probabilities of being hired will be downward biased to some extent, because establishments/jobs with relatively high demand for blacks receive disproportionately many applicants, of whom somewhat fewer are then hired.

Still, some important differences appear in these conditional probabilities. When comparing suburban establishments to those located in the central city, the likelihood of black applicants being hired is relatively lowest in clerical/sales and service jobs, in the trade and service industries, and in small and medium-sized establishments. Comparing blacks with Hispanics, the latter are more likely to be hired across a wide range of jobs and establishments, with the gap between the two groups being particularly large in suburban establishments. Furthermore, this fact is not attributable to the high concentration of Hispanics in Los Angeles, since it is true within that metropolitan area as well as in the others considered here.

By gender, black males are relatively more likely than black females to be hired into professional/managerial jobs and those requiring college, especially in the central city. But they have more trouble than black females being hired into jobs requiring less education, especially in the suburbs. The tendency for black males to be hired into clerical/sales jobs in small suburban establishments, especially in retail trade, is strikingly low. 
Of course, it is hard to infer the exact extent to which these patterns in relative hiring rates reflect differences in discriminatory employer behavior as opposed to other factors (such as the relative quality of applicants), but at least some of the city/suburban differences in hiring suggest discriminatory patterns. In particular, the greater reluctance of suburban employers to hire blacks in smaller establishments suggests greater discrimination there, perhaps because employers feel less vulnerable to legal challenges under EEO laws (Holzer, forthcoming). Also, the low representation of blacks in white-collar or service jobs in the trade sectors suggests that employers may be catering to the discriminatory preferences (real or perceived) of their customers (Holzer and Ihlanfeldt, forthcoming). The particular aversion to hiring black males into many of these jobs is consistent with the qualitative evidence of greater employer fear of this group that was mentioned above. The greater success of Hispanic applicants overall suggests some important differences in employer perceptions and preferences across these groups. These, along with the choices of the applicants themselves, should have implications not only for where blacks work but for their overall employment outcomes. ${ }^{16}$

\section{B. Determinants of Applications from Blacks: Regression Results}

In this section I present more formal statistical analyses of the determinants of black applicants to jobs and establishments, based on regression results for equation (1). All equations are sample-weighted. Some results are presented for all jobs while others are presented only for jobs not requiring college degrees. ${ }^{17}$

Results from four specifications are presented in Table 3. In the first specification, I include basic characteristics of jobs and establishments, such as skill demands on the job (measured by whether

${ }^{16}$ These results might still be consistent with some discrimination against Hispanic applicants in the labor market (Kenney and Wissoker, 1994), but they suggest that Hispanic applicants are more able than blacks to locate sectors in the economy where they will not face such discrimination.

${ }^{17}$ To be consistent across equations (1) and (2), I present ordinary least squares estimates only in Table 3. These equations have also been estimated using tobit, which generates qualitatively similar estimates that are occasionally a bit larger than those presented here. 
TABLE 3

Regressions for the Percentage of Applications Accounted for by Blacks

\begin{tabular}{|c|c|c|c|c|c|c|c|c|c|c|}
\hline & \multirow{2}{*}{\multicolumn{2}{|c|}{$\frac{\text { All Jobs }}{1}$}} & \multicolumn{8}{|c|}{ Noncollege Jobs } \\
\hline & & & & 1 & & 2 & & 3 & & 4 \\
\hline \multicolumn{11}{|l|}{ Educational Requirements } \\
\hline College degree & -.143 & $(.029)$ & - & & - & & - & & - & \\
\hline High school diploma & -.040 & $(.020)$ & -.042 & $(.019)$ & -.038 & $(.018)$ & -.029 & $(.017)$ & -.029 & $(.017)$ \\
\hline \multicolumn{11}{|l|}{ Occupations } \\
\hline Clerical/sales & .018 & $(.023)$ & .008 & $(.026)$ & -.005 & $(.025)$ & -.026 & $(.023)$ & -.020 & $(.023)$ \\
\hline Crafts & -.034 & $(.035)$ & -.044 & $(.036)$ & -.065 & $(.035)$ & -.063 & $(.031)$ & -.048 & $(.031)$ \\
\hline Operatives/laborers & .028 & $(.032)$ & .015 & $(.033)$ & .012 & $(.031)$ & -.005 & $(.028)$ & -.003 & $(.028)$ \\
\hline Service & .069 & $(.031)$ & .052 & $(.033)$ & .028 & $(.031)$ & .002 & $(.028)$ & .005 & $(.028)$ \\
\hline \multicolumn{11}{|l|}{ Industries } \\
\hline Construction & -.074 & $(.060)$ & -.087 & $(.057)$ & -.076 & $(.054)$ & -.005 & $(.049)$ & -.017 & $(.049)$ \\
\hline Manufacturing & -.049 & $(.029)$ & -.068 & $(.028)$ & -.062 & $(.027)$ & .006 & $(.026)$ & .001 & $(.026)$ \\
\hline TCU & .026 & $(.041)$ & .043 & $(.042)$ & .028 & $(.040)$ & .077 & $(.037)$ & .067 & $(.036)$ \\
\hline Wholesale trade & -.082 & $(.037)$ & -.073 & $(.037)$ & -.066 & $(.036)$ & .011 & $(.032)$ & .008 & $(.033)$ \\
\hline FIRE/services & -.007 & $(.024)$ & -.033 & $(.024)$ & -.043 & $(.023)$ & -.020 & $(.020)$ & -.025 & $(.020)$ \\
\hline Public & -.167 & $(.066)$ & -.203 & $(.063)$ & -.191 & $(.060)$ & -.119 & $(.054)$ & -.169 & $(.055)$ \\
\hline \multicolumn{11}{|l|}{ Employees } \\
\hline $1-50$ & -.048 & $(.018)$ & -.089 & $(.020)$ & -.096 & $(.019)$ & -.092 & $(.017)$ & -.072 & $(.018)$ \\
\hline $50-100$ & -.031 & $(.027)$ & -.064 & $(.029)$ & -.059 & $(.027)$ & -.064 & $(.025)$ & -.053 & $(.025)$ \\
\hline Unionization & .091 & $(.024)$ & .087 & $(.027)$ & .034 & $(.027)$ & .036 & $(.024)$ & .048 & $(.024)$ \\
\hline Central city & .139 & $(.019)$ & .174 & $(.020)$ & .069 & $(.022)$ & .052 & $(.019)$ & .055 & $(.019)$ \\
\hline Public transit within $1 / 4$ mile & - & & - & & .064 & $(.018)$ & .052 & $(.016)$ & .052 & $(.016)$ \\
\hline Relative distance to blacks & - & & - & & -.453 & $(.049)$ & -.280 & $(.045)$ & -.271 & $(.045)$ \\
\hline Black customers & - & & - & & - & & .555 & $(.083)$ & .546 & $(.082)$ \\
\hline $\begin{array}{l}\text { Black customers*customer } \\
\text { contact }\end{array}$ & - & & - & & - & & .048 & $(.088)$ & .050 & $(.087)$ \\
\hline Black respondent & - & & - & & - & & .092 & $(.030)$ & .073 & $(.030)$ \\
\hline Affirmative action in recruiting & - & & - & & - & & - & & -.007 & $(.015)$ \\
\hline
\end{tabular}


TABLE 3, continued

\begin{tabular}{|c|c|c|c|c|c|c|}
\hline & \multirow{2}{*}{$\begin{array}{c}\text { All Jobs } \\
1\end{array}$} & \multicolumn{5}{|c|}{ Noncollege Jobs } \\
\hline & & 1 & 2 & 3 & & 4 \\
\hline \multicolumn{7}{|l|}{ Recruiting Methods } \\
\hline Signs/walk-ins & - & - & - & - & .007 & $(.017)$ \\
\hline Referrals & - & - & - & - & .021 & $(.022)$ \\
\hline Newspapers & - & - & - & - & .035 & $(.015)$ \\
\hline State/community agencies & - & - & - & - & .074 & $(.017)$ \\
\hline Private agencies & - & - & - & - & .010 & $(.019)$ \\
\hline Unions/schools & - & - & - & - & -.007 & $(.016)$ \\
\hline $\mathrm{R}^{2}$ & .235 & .259 & .326 & .456 & .473 & \\
\hline Sample size & 1235 & 1141 & 1141 & 1141 & 1141 & \\
\hline
\end{tabular}

Notes: Standard errors are in parentheses. The omitted categories are "No requirements" for Educational Requirements, "Managers and professionals" for Occupations, "Retail trade" for Industries, and "> 100" for Employees. 
the job requires college or high school degrees, and by occupation dummies). I also include a variety of establishment-level characteristics, such as location between and within MSAs (measured by MSA dummies and dummies for central-city locations within MSAs rather than suburbs), industry, establishment size, and presence of collective bargaining.

The next two specifications include additional measures that might account for the geographic patterns of applicants within metropolitan areas. The first of these includes proxies for the cost borne by blacks in applying to an establishment: whether the establishment is located within one-quarter mile of a public transit stop and its relative distance to the black and white populations in an MSA. ${ }^{18}$ The next equation also adds a measure of the fraction of customers at the establishment who are black as well as a dummy variable for whether the survey respondent (who is in charge of hiring) is black, as measures of employer preferences for blacks. The first of these variables is interacted with a dummy for whether the job involves direct contact between customers and employees in the job, since the race of customers should only be directly relevant where such contact exists (Holzer and Ihlanfeldt, forthcoming). To the extent that the race of customers affects applicants (or employment) in jobs not involving contact, we might infer that the effect reflects some other characteristic of the establishment, such as its information/contacts or simply visibility within the black community.

Finally, the fourth specification includes more explicit measures of information dissemination among potential black applicants, such as a dummy for whether the establishment uses affirmative action when recruiting, and dummies for whether each of a set of recruitment methods was used in hiring for the last-filled position.

\footnotetext{
${ }^{18}$ The distance of each establishment to various residential population groups has been calculated as the weighted average of the distance between the centroids of the establishment's census tract and those of each other census tract in the metropolitan area, weighted by the percentage of the relevant population group that lives in that census tract (Holzer and Ihlanfeldt, 1996). The relative distance to the black population is then the ratio of average distance to the black and white populations, respectively.
} 
A number of findings in the summary data above are confirmed in Table 3. Black applicants are less likely to apply for jobs that require formal degrees, especially college, and they are somewhat more likely to apply for unskilled occupations (such as service jobs) than for professional/managerial ones, even controlling for educational requirements. By industry, blacks are more likely to apply to the utilities (especially among the less-educated) and less likely to apply to the construction, manufacturing, wholesale trade, and public sectors. Blacks are also more likely to apply to larger or more heavily unionized establishments. ${ }^{19}$ Most of these differences can also be found below with regard to the probabilities of black applicants being hired-in other words, blacks are more likely to apply to jobs where their expected benefits (in terms of being hired) are higher as well. ${ }^{20}$ The establishments that receive many black applicants are also those that tend to pay relatively higher wages to blacks, as noted above. Many of the estimated effects are also larger when the sample is limited to jobs that do not require college degrees, though similar patterns can generally be observed for both samples.

By geographic location, it is clear that the tendency of establishments in central cities to obtain more black applicants continues to hold (in the first column of Table 3), even after controlling for many other characteristics of establishments and jobs. But the size of this effect is dramatically reduced in column 2. The results suggest that proximity to public transit and to the black residential population can account for most of the greater tendency of central-city firms to receive applications from blacks. Thus, differences in the costs of delivering applications to firms appear largely to account for the geographic patterns observed in where blacks apply for work.

The race of its customers also has a large effect on the tendency of blacks to apply at an establishment. The additional effect of customers in contact jobs is positive as well, but much smaller

\footnotetext{
${ }^{19}$ Though the individual coefficients on occupation and industry dummies are often not significant by conventional standards, F-statistics indicate that both of these categories of variables are jointly significant in all specifications presented.

${ }^{20}$ The one notable exception is the suburban public sector, where few blacks apply despite relatively high probabilities of being hired (as seen in Table 2).
} 
and not significant. This suggests that the primary effect of having black customers on the receipt of black applicants is through some other mechanism, such as information or visibility. ${ }^{21}$ Having black respondents in charge of hiring also has a positive effect on the probability of receiving applications from blacks, perhaps indicating another mechanism through which information about available jobs is disseminated in the black community (Raphael, Stoll, and Holzer, 1998). Finally, we note that some recruiting methods—especially state or community agencies and newspaper ads—are more likely to generate black applicants than are other methods.

Table 4 presents similar results to those from columns 1 and 4 of Table 3, but separately for establishments located in central cities and those in the suburbs. Results are again presented for all jobs and for those that do not require college. The results generally confirm findings from Table $2 .{ }^{22}$ On the one hand, the educational requirements and occupations generally have larger effects on the race of applicants at establishments in the central city, with those requiring less skill getting many more applicants there. On the other hand, other characteristics such as industry and establishment size generally have larger effects in the suburbs. These results confirm that less-educated blacks apply much less frequently for suburban jobs, especially at smaller (or generally less salient) establishments.

A few specific cases present striking contrasts between the central-city and suburban effects. In particular, public sector jobs receive far fewer black applicants in the suburbs than do other industries, although this is not the case in central cities. State agencies, newspapers, and walk-ins generate many black applicants in central cities but fewer in the suburbs. ${ }^{23}$ In each case, these applicant flows seem to

\footnotetext{
${ }^{21}$ Controlling for race of customers also eliminates some of the industry effects noted earlier, as "customers" outside of the retail trade and service sectors are generally likely to be other business owners or managers who are frequently white.

${ }^{22} \mathrm{~F}$-tests generally reject equality in these estimated equations between the two geographic areas.

${ }^{23}$ The differences between central cities and suburbs in the effects of recruitment methods on applicant flows are generally not significant for individual methods. However, as a group they are significant in the central city at the 5 percent level (but not in the suburbs).
} 
TABLE 4

Regressions for the Percentage of Applications Accounted for by Blacks: Central City versus Suburbs

\begin{tabular}{|c|c|c|c|c|c|c|c|c|c|c|c|c|}
\hline & \multicolumn{6}{|c|}{ Central City } & \multicolumn{6}{|c|}{ Suburbs } \\
\hline & \multirow{2}{*}{\multicolumn{2}{|c|}{$\begin{array}{c}\text { All Jobs } \\
1 \\
\end{array}$}} & \multicolumn{4}{|c|}{ Noncollege Jobs } & \multirow{2}{*}{\multicolumn{2}{|c|}{$\begin{array}{c}\text { All Jobs } \\
1 \\
\end{array}$}} & \multicolumn{4}{|c|}{ Noncollege Jobs } \\
\hline & & & & 1 & 2 & 2 & & & & 1 & & 2 \\
\hline \multicolumn{13}{|l|}{ Educational Requirements } \\
\hline College degree & -.122 & $(.059)$ & - & & - & & -.059 & $(.034)$ & - & & - & \\
\hline High school diploma & -.010 & $(.042)$ & -.011 & $(.040)$ & .025 & $(.036)$ & -.018 & $(.025)$ & -.021 & $(.023)$ & -.033 & $(.022)$ \\
\hline \multicolumn{13}{|l|}{ Occupations } \\
\hline Clerical/sales & -.001 & $(.045)$ & .056 & $(.053)$ & .063 & $(.047)$ & -.009 & $(.028)$ & -.020 & $(.032)$ & -.051 & $(.030)$ \\
\hline Crafts & -.011 & $(.080)$ & -.033 & $(.085)$ & -.026 & $(.076)$ & -.055 & $(.040)$ & -.060 & $(.041)$ & -.061 & $(.037)$ \\
\hline Operatives/labor & .119 & $(.066)$ & .167 & (.069) & .134 & $(.060)$ & .004 & $(.038)$ & -.003 & $(.038)$ & -.017 & $(.036)$ \\
\hline Service & .177 & $(.062)$ & .193 & $(.066)$ & .112 & $(.058)$ & .022 & $(.037)$ & -.003 & $(.040)$ & -.030 & $(.037)$ \\
\hline \multicolumn{13}{|l|}{ Industries } \\
\hline Construction & -.026 & $(.126)$ & -.024 & $(.123)$ & .001 & (.109) & -.033 & $(.073)$ & -.060 & $(.068)$ & -.017 & $(.063)$ \\
\hline Manufacturing & -.045 & $(.062)$ & -.071 & $(.061)$ & .034 & $(.057)$ & -.019 & $(.034)$ & -.044 & $(.033)$ & .003 & $(.033)$ \\
\hline TCU & .012 & $(.071)$ & .014 & $(.082)$ & .045 & $(.072)$ & .154 & $(.055)$ & .126 & $(.051)$ & .131 & $(.047)$ \\
\hline Wholesale trade & -.070 & $(.076)$ & -.093 & $(.074)$ & .039 & $(.067)$ & .002 & $(.048)$ & -.001 & $(.047)$ & .037 & $(.043)$ \\
\hline FIRE/services & -.023 & $(.047)$ & -.047 & (.047) & -.035 & $(.042)$ & .011 & $(.029)$ & -.014 & $(.028)$ & .007 & $(.027)$ \\
\hline Public & .056 & $(.169)$ & .014 & $(.189)$ & .029 & $(.163)$ & -.136 & $(.070)$ & -.171 & $(.065)$ & -.158 & $(.062)$ \\
\hline \multicolumn{13}{|l|}{ Employees } \\
\hline $1-50$ & -.001 & $(.036)$ & -.023 & $(.040)$ & -.033 & $(.038)$ & -.120 & $(.024)$ & -.157 & $(.025)$ & -.132 & $(.025)$ \\
\hline $51-100$ & .029 & $(.047)$ & -.021 & $(.054)$ & -.005 & $(.049)$ & -.138 & $(.036)$ & -.143 & $(.036)$ & -.134 & $(.033)$ \\
\hline Unionization & .184 & $(.053)$ & .118 & $(.058)$ & .081 & $(.053)$ & -.037 & $(.031)$ & -.011 & $(.034)$ & -.007 & $(.032)$ \\
\hline Public transit within $1 / 4$ mile & - & & - & & .019 & $(.035)$ & - & & - & & .062 & $(.021)$ \\
\hline Relative distance to blacks & - & & - & & -.346 & $(.132)$ & - & & - & & -.160 & $(.055)$ \\
\hline
\end{tabular}


TABLE 4, continued

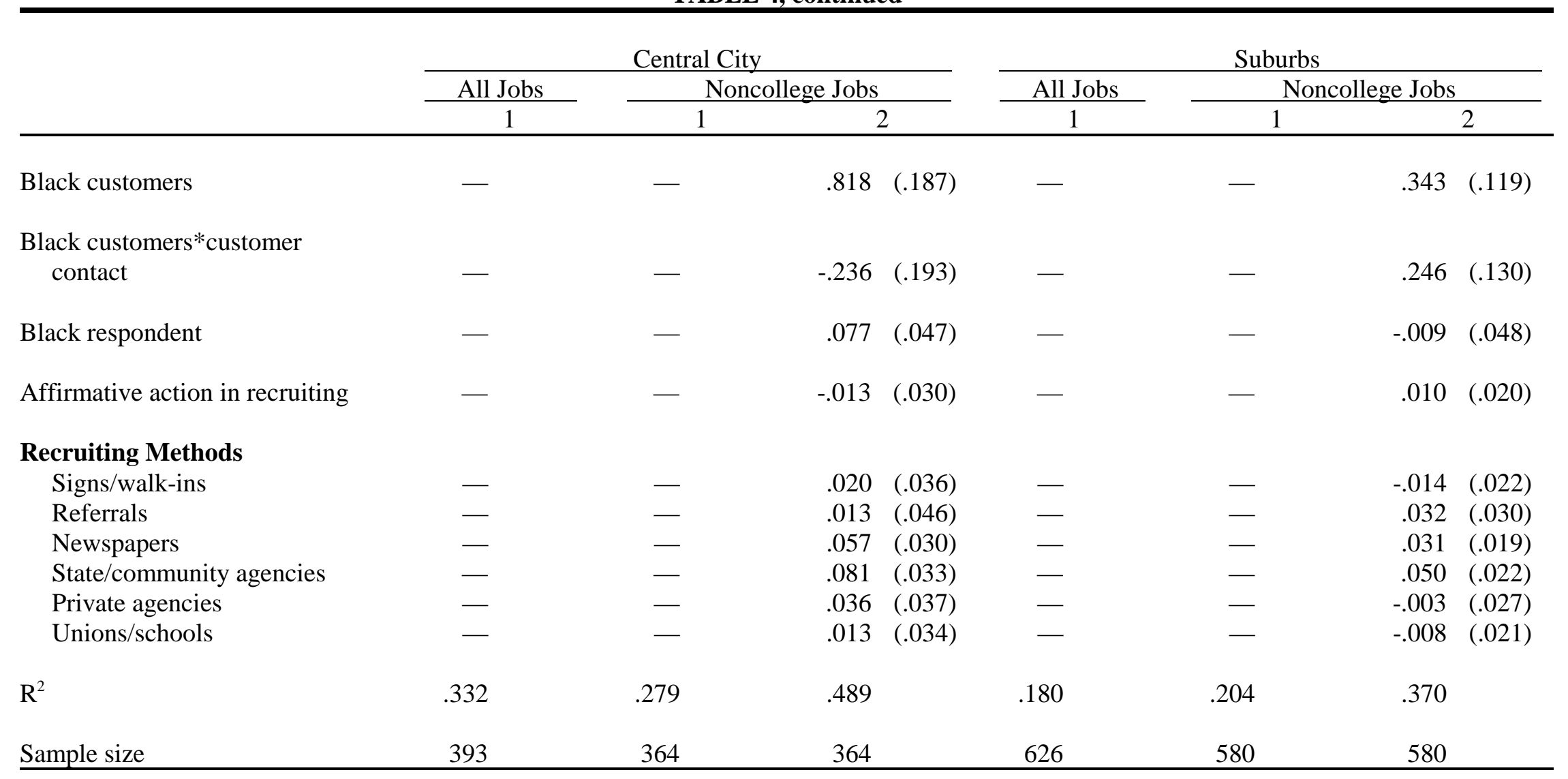

Note: Columns with the heading of 2 in this table and those that follow correspond to specification 4 of Table 3. 
reflect local geographic factors, such as who the constituents of the local public sector are or the general proximity of firms to various population groups.

\section{Ratios of Black New Hires to Applicants: Regression Results}

Table 5 presents results for the conditional demand for black applicants on the part of employers. I measure this demand by the effect of any given characteristic on the ratio of black new hires to black applicants, based on estimates from equations (1) and (2) that are used to generate predicted values of each (as described in Section III). ${ }^{24}$ Part A of Table 5 presents results for all jobs and for those that do not require college degrees; part B presents results for noncollege jobs only in the central cities versus the suburbs. Results are for the same two specifications used in Table 4.

The predicted values are calculated at the mean level of each independent variable except for the one in question, which in most cases is a categorical variable taking on the value of one or zero. Where continuous instead of categorical variables are considered, I generally use values representing the 25th and 75th percentiles of the distribution for that variable. Standard errors on the ratios of these predictions are provided as well.

As noted above, the results of part A of Table 5 parallel those of Tables 3 to a large extent, indicating that blacks are more likely to apply for jobs where their probabilities of gaining employment are relatively higher. Thus, black applicants are less likely to be hired in jobs requiring college or in professional/managerial jobs (especially in central cities). Black applicants are also more likely to be hired in the utilities, in medium-sized and large establishments, and in establishments with black respondents or customers, where the latter is especially true in jobs with customer contact. These

\footnotetext{
${ }^{24}$ The application and new hire equations here are estimated as a system using Seemingly Unrelated Regressions. Descriptions of the methods by which I calculated standard errors on the predicted values and the ratios of predicted values are available from the author.
} 
TABLE 5

Ratio of Predicted Values: New Hires to Applicants

A.

Educational Requirements

College degree not required

College degree required

High school diploma not required

High school diploma required

\section{Occupations}

Managerial/professional

Clerical/sales

Crafts

Operatives/labor

Service

\section{Industries}

Construction

Manufacturing

TCU

Wholesale trade

Retail trade

FIRE/services

Public

\section{Employees}

$1-50$

51-100

$>100$

\section{Unionization}

Nonunion

Fully Unionized

\section{Location}

Central city

Suburbs

Other

\section{Public Transit within $1 / 4$ Mile}

No

Yes
All Jobs

\section{1}

$.392(.137)$

$.782(.059)$

$.564(.056)$
Noncollege Jobs

2 
TABLE 5, continued

A.

All Jobs Noncollege Jobs 1 2 1

2

\begin{tabular}{|c|c|c|c|c|}
\hline \multicolumn{5}{|c|}{ Relative Distance to Blacks } \\
\hline 25th percentile & - & $.673(.043)$ & - & $.701(.043)$ \\
\hline 75th percentile & - & $.664(.054)$ & - & $.735(.057)$ \\
\hline \multicolumn{5}{|l|}{ Black Customers } \\
\hline 25 th percentile & - & $.455(.086)$ & - & $.536(.075)$ \\
\hline 75th percentile & - & $.763(.044)$ & - & $.837(.052)$ \\
\hline \multicolumn{5}{|c|}{ Black Customers*Customer Contact } \\
\hline 25th percentile & - & $.464(.078)$ & - & $.541(.081)$ \\
\hline 75th percentile & - & $.705(.042)$ & - & $.766(.051)$ \\
\hline \multicolumn{5}{|l|}{ Black Respondent } \\
\hline No & - & $.645(.036)$ & - & $.701(.036)$ \\
\hline Yes & - & $.936(.120)$ & - & $.876(.118)$ \\
\hline
\end{tabular}

B.

Noncollege Jobs

\begin{tabular}{lllll}
\hline \multicolumn{2}{c}{ Central City } & & \multicolumn{2}{c}{ Suburbs } \\
\cline { 5 - 6 } \cline { 4 - 5 } & 2 & & 1 & 2
\end{tabular}

\section{Educational Requirements}

High school diploma not required .739 (.095)

High school diploma required

$.762(.056)$

$\begin{array}{lll}.769(.103) & .931(.116) & .908(.115) \\ .751(.055) & .569(.076) & .575(.078)\end{array}$

\section{Occupations}

Managerial/professional

Clerical/sales

Crafts

Operatives/labor

Service

$\begin{array}{rrrrr}.378(.172) & .319(.164) & .808(.166) & .831(.155) \\ .741(.070) & .770(.069) & .585(.101) & .621(.111) \\ 1.182(.293) & 1.045(.277) & .565(.230) & .593(.210) \\ .785(.111) & .815(.116) & .841(.151) & .705(.151) \\ .865(.104) & .838(.122) & .697(.167) & .737(.176)\end{array}$

\section{Industries}

Construction

Manufacturing

TCU

Wholesale trade

Retail trade

FIRE/services

Public

$\begin{array}{rrrrr}.555(.322) & .687(.328) & .864(.519) & .758(.464) \\ .410(.141) & .464(.128) & .399(.148) & .279(.141) \\ .954(.186) & .948(.189) & 1.334(.197) & 1.409(.216) \\ .962(.210) & .982(.173) & .688(.239) & .729(.227) \\ 1.007(.107) & .917(.117) & .656(.134) & .742(.160) \\ .699(.070) & .702(.076) & .719(.109) & .779(.114) \\ 1.031(.494) & 1.062(.515) & 1.865(2.101) & 2.384(3.207) \\ & & & \end{array}$


TABLE 5, continued

B.

Noncollege Jobs

\begin{tabular}{lllll}
\hline \multicolumn{3}{c}{ Central City } & \multicolumn{3}{c}{ Suburbs } \\
\cline { 5 - 6 } \cline { 4 - 5 } & 2 & & 1 & 2
\end{tabular}

\section{Employees}

$1-50$

51-100

$>100$

Unionization

Nonunion

Fully unionized

Public Transit within $1 / 4$ Mile

No

Yes

Relative Distance to Blacks

25th percentile

75th percentile

Black Customers

25th percentile

75th percentile
$.605(.065)$

$.926(.134)$

$.951(.089)$

$.839(.054)$

$.331(.127)$

$.842(.053)$

$.278(.135)$

$.636(.067)$

$1.007(.214)$

$.620(.067)$

$1.108(.225)$

$\begin{array}{llll}- & .725(.104) & - & .705(.114) \\ - & .764(.052) & - & .670(.080)\end{array}$

$\begin{array}{llll}- & .712(.056) & - & .660(.075) \\ - & .800(.062) & - & .716(.097)\end{array}$

- $\quad .601(.124) \quad-\quad$ - $\quad .745(.129)$

- $\quad .839(.071) \quad-\quad .652(.077)$

Black Customers*Customer Contact

25th percentile

75th percentile

$-$

$-$

$.699(.113)$

$.776(.058)$

$-$

$.365(.142)$

$.624(.070)$

\section{Black Respondent}

No

$\begin{array}{lrr}- & .705(.051) & - \\ - & 1.040(.131) & -\end{array}$

$.674(.062)$

Yes 
differences can be observed despite the fact that many of the hiring probabilities where demand is low are likely upward biased by the low percentages of applications received in the first place.

Comparing central-city establishments with those in the suburbs in part B of Table 5, we find some similarities as well as some differences in hiring patterns across locations. For instance, smaller establishments hire relatively fewer black applicants in both locations, and the race of customers and respondents is important in both (though the particular effect of having contact with white or black customers matters more in the suburbs). But hiring patterns by education and occupation differ somewhat across the two locations (with educational attainment having larger effects in the suburbs but professional/managerial status of jobs mattering more in the city), and unions exert a relatively more positive influence on the hiring of blacks in the suburbs.

By industry, we also find some similarities and some differences in hiring patterns between cities and suburbs. On the one hand, hiring rates for blacks are high in the public sector, regardless of location, ${ }^{25}$ and they are relatively low in manufacturing, especially in many of the newer facilities being located in suburban areas. The high probability that black applicants to suburban public sector jobs will be hired suggests that other factors (such as informational limitations or high transit costs) are substantially reducing black employment opportunities in this sector, while the low probability in manufacturing might reflect growing skill needs in that sector related to a recent high level of technological change (Berman, Bound, and Griliches, 1994) ${ }^{26}$ On the other hand, the probabilities of blacks being hired in wholesale and retail trade establishments and in service jobs are relatively high in central cities but low in the suburbs, consistent with results presented earlier.

One noteworthy difference between these results and those presented earlier is that the overall effect of location in the central city seen in part A of Table 5 does not generate a higher likelihood of

\footnotetext{
${ }^{25}$ Of course, the standard errors on these estimates are quite large as well.

${ }^{26}$ This interpretation does, however, beg the question of why the employment of Hispanic applicants is higher than that of black applicants in manufacturing, as seen in Table 2.
} 
being hired once other characteristics of establishments and jobs are controlled for. Thus, it may not be location per se that generates the lower tendency of black applicants to be hired in the suburbs, but rather other characteristics of the jobs and establishments located there (such as their generally smaller size and their lesser tendency to be unionized or in the service sector). Nevertheless, the lower tendency of these establishments to hire black applicants, regardless of the cause, must be taken into account when we consider the effects of labor market policies designed to improve the representation of blacks in these establishments. And the results of part B of Table 5 still indicate some important differences between the two areas in relative hiring probabilities within specific industry sectors.

Finally, I have computed similar application equations and ratios of predicted values for black males versus black females and for Hispanics. These results, available from the author, largely confirm the results presented in Tables 1 and 2 above.

\section{Do These Factors Affect Wage and Employment Outcomes of Blacks?}

Search theory suggests, and the data presented above confirm, that black applicants (like any other group) are relatively rational, in the sense that they are more likely to apply to those establishments where they have higher expected benefits (in terms of relative wages and their probabilities of being hired). To the extent that this is true, a reallocation of applicants across establishments would not necessarily lead to improved employment outcomes for that group. On the other hand, the data also confirm that differential costs of search (because of uneven residential concentrations and transportation difficulties), and perhaps limited information flows, reduce the flow of black applicants to suburban jobs as well. If these forces are significant, there might be some scope for improving the employment outcomes of blacks by redistributing the applicant flow, perhaps by lowering the search costs or improving information flows about suburban jobs.

Unfortunately, it is somewhat difficult to infer from the data presented above what the magnitudes of such effects would be. Simply reallocating applicants across jobs which are no more 
prevalent and offer no more compensation in one area than another might do little good. Given the lower probabilities that black applicants currently face of being hired at suburban jobs, such a reallocation might actually reduce their employment opportunities. On the other hand, if we can show that the areas or firms to which blacks currently apply have fewer numbers of jobs available (relative to searchers) or pay lower wages than those located elsewhere, then a stronger case can be made for the idea that reallocating applicants will improve overall employment outcomes for that group.

In fact, such evidence has already been presented elsewhere, using these and other data. For instance, while black residential areas are often located nearer to overall employment than are white areas (Holzer and Ihlanfeldt, 1996), they are often farther from the areas of greatest new net job growth (Kain, 1992; Raphael, 1998). Also, Holzer (1996) shows that, after adjusting for commuter flows, the ratio of jobs to people in the cities is lower than in the suburbs of most areas. Furthermore, Ihlanfeldt (forthcoming) employs the same data that I have used here to show that vacancy rates in low-skill jobs (particularly blue-collar and service jobs) are generally higher in areas that are farthest from black residential concentrations. All of these findings suggest that a reallocation of black applicants would increase the net number of jobs available to them and therefore improve their overall employment opportunities.

Results on relative wages across establishments are similar. I have estimated equations in which the dependent variable is the log of the starting hourly wage of the job, and the independent variables include the percentage of applicants to the job who are black, as well as controls for the characteristics of establishments, jobs, and workers hired (such as age, education, and gender). The results tell a clear story: The earnings of blacks are reduced by a high flow of black applicants, while the earnings of other workers are unaffected. Indeed, the results suggest that moving a black employee from an establishment 
with only black applicants to one with only white applicants would increase that employee's wages by $30-40$ percent. $^{27}$

The results are clearly consistent with a "crowding" story, in which the wages of blacks are driven downward by a large supply of applicants chasing a limited number of jobs. Other unobserved characteristics of these establishments and/or jobs, such as lower product market rents to be shared with employees or poorer capital/technology, might generate the same results (e.g., Bates, 1993; Holzer and Ihlanfeldt, forthcoming). Under either scenario, a reallocation of black applicants toward other firms and areas would improve their wages. Only if the lower wages of blacks in these establishments reflect unobserved characteristics of the workers themselves (Hirsch and McPherson, 1994) would there be no return to such a reallocation in the form of higher wages for blacks.

\section{CONCLUSION AND POLICY IMPLICATIONS}

In this paper, I analyze the determinants of black applicant flows across establishments as well as the conditional probabilities that these applicants will be hired. I find that establishments located in the central cities of large metropolitan areas receive many more applications from black workers than do establishments in the suburbs; these applicants are more likely to be hired in the city as well. Hispanic applicants generally are hired at higher rates than are black applicants, while black female applicants receive more job offers than their black male counterparts.

Our results show that a variety of characteristics of establishments and jobs, especially their location, matter a great deal in terms of the extent to which blacks apply for work and are hired. The greater tendency of blacks to apply for jobs located in central cities rather than suburbs is mostly accounted for by the greater proximity of those jobs to their own residences and to public transit. Thus,

\footnotetext{
${ }^{27}$ Including the fractions of blacks among customers or whether the respondent is black reduces the magnitudes of these estimates considerably but does not eliminate them.
} 
the relative costs of applying seem to have important effects on the geographic concentration of applicant flows. The race of customers and of those responsible for hiring affects black applicant flows to firms, as do the recruitment methods used in the suburbs and in the cities; these factors suggest the importance of information in accounting for the race of applicants. The flow of less-educated black applicants to suburban jobs, especially in smaller establishments, is particularly low relative to that in the central city.

But we also find a relatively lower tendency on the part of suburban employers to hire blacks into some categories of jobs and industries, such as clerical/sales and service jobs and those in wholesale and retail trade. These findings are also consistent with the notion that blacks are less likely to be hired into establishments where customers and those responsible for hiring are white. Small establishments in the suburbs (as well as the central city) also have relatively lower tendencies to hire those blacks who do apply for work there, perhaps due to less concern over EEO pressure. Black males are less successful than their female counterparts in gaining employment in retail trade or service sector jobs for the lesseducated in the suburbs. In contrast, Hispanics are more likely to apply and far more likely to be hired into blue-collar jobs and some segments of the manufacturing and service sectors. But there are some segments of the suburban labor market (such as public sector jobs) to which few blacks apply despite apparently high probabilities of their being hired there.

These findings have some significant implications for urban labor market policies. For one thing, it is important to reduce the costs incurred by central-city blacks when they apply to suburban employers and to improve the flow of information about employment opportunities there. We especially need to improve the flow of less-educated black applicants to smaller and medium-sized suburban establishments where few such blacks now apply, despite the relatively greater tightness of those labor markets and relatively higher wages for less-skilled workers there.

Of course, any policies that improve the access of central-city residents to suburban housing would help to accomplish this, in addition to overcoming the negative effects on educational and 
behavioral outcomes associated with growing up in racially and/or economically segregated urban environments (Cutler and Glaeser, 1997; Jargowsky, 1997). The potential benefits, but also limitations, of doing so are discussed at length elsewhere (e.g., Rosenbaum and Popkin, 1991; Katz, Kling, and Liebman, 1997; Haar, 1996; Briggs, 1997).

More modest and less politically controversial approaches take residences as given and focus on the "mobility" of residents to suburban jobs. Transportation assistance, job placement activities, and job search assistance all can be approaches used by labor market intermediaries, at relatively low cost per job applicant, to improve the flow of black applicants to suburban employers. Indeed, many current discussions of aiding the "welfare-to-work" transition for unskilled women focus on these kinds of activities (e.g., Roberts, 1998), and many states currently use some version of these approaches. As noted above, the "Bridges to Work" demonstration project highlights these approaches, as have other such programs that have been undertaken (but not seriously evaluated) at the local level (e.g., Hughes and Sternberg, 1992). Even "school-to-work" programs can sometimes be used to bridge these gaps if suburban employers are willing to become involved with schools in inner-city areas. And some apparently successful training programs for disadvantaged workers, such as the Center for Employment and Training (CET), rely heavily on their links to local employers throughout the metropolitan area to provide customized training and successful job placements for participating workers. ${ }^{28}$

But the success of these approaches will clearly depend on the willingness of employers to hire the applicants generated through this process, and the data here suggest that this willingness is relatively low in many key sectors of the suburban labor market. Of course, the hiring of black applicants may depend on a number of factors besides discriminatory preferences of suburban employers, such as the relative skills of the applicants generated, the strength of ties between the local intermediary and area

\footnotetext{
${ }^{28}$ See Harrison and Weiss (1998) for more discussion of CET and other examples of apparently successful local labor market intermediaries.
} 
employers, and the tightness of the local labor market. When employers have confidence in the intermediaries, they will take more seriously the information about job candidates that the latter provide. When labor markets are unusually tight (as is currently the case), employers are more willing than usual to consider sources of employees that they otherwise would not.

If an increased flow of apparently qualified applicants does not then generate a commensurate increase in their employment rates, some legal basis might exist for targeting these establishments for greater enforcement of EEO laws. The data presented here suggest that small establishments with many white customers, especially those in the retail trade and service sectors, tend to hire relatively few of the blacks (especially males) who apply for jobs. Mobility programs that increase the supply of black applicants to such suburban establishments might, therefore, be complementary with targeted EEO enforcement that should raise the demand for such applicants.

But cost-effective ways of monitoring the behavior of small establishments would have to be developed, and data would have to be available on the demographics of their applicant pool. The use of auditors to infer the willingness of employers to hire qualified minority applicants is one approach to this problem, although the legal status of such auditors remains unresolved. Also, a strategy of relying on the "stick" of EEO enforcement against recalcitrant employers would not be complementary with the "carrot" of using local intermediaries to develop good relations with these same employers; presumably the former would only be used in cases where the latter proves ineffective.

Finally, the need to ensure that black applicants in the suburbs have good credentials and job qualifications remains critical as well. School reform efforts that aim to improve the basic cognitive skills of inner-city students, as well as efforts to improve the "school-to-work" transition and enable more of these young people to gain good early work experience, must also be key components of any strategy to improve the access of young urban blacks to the suburban job market (Holzer, 1998). 


\section{References}

Bates, Timothy. 1993. Banking on Black Enterprise: The Potential of Emerging Firms for Revitalizing Urban Economies. Washington, DC: Joint Center for Political and Economic Studies.

Berman, Eli, John Bound, and Zvi Griliches. 1994. "Changes in the Demand for Skilled Labor within U.S. Manufacturing: Evidence from the Annual Survey of Manufacturers." Quarterly Journal of Economics 109 (4): 367-397.

Bloch, Farrell. 1994. Antidiscrimination Law and Minority Employment: Recruitment Practices and Regulatory Constraints. Chicago: University of Chicago Press.

Borjas, George. 1992. "Ethnic Capital and Intergenerational Mobility." Quarterly Journal of Economics 107 (1): 123-150.

Bound, John, and Harry Holzer. 1993. "Industrial Shifts, Skills Levels, and the Labor Market for White and Black Males." Review of Economics and Statistics 75: 387-396.

Bound, John, and Harry Holzer. 1996. "Demand Shifts, Supply Adjustments, and Labor Market Outcomes, 1980-90.” Working Paper, National Bureau of Economic Research.

Briggs, Xavier de Sousa. 1997. "Moving Up v. Moving Out: Neighborhood Effects in Housing Mobility Programs." Housing Policy Debate 8 (1): 195-234.

Carrington, William, Kristin McCue, and Brooks Pierce. 1995. "Using Establishment Size to Measure the Impact of Title VII and Affirmative Action.” Mimeographed, Department of Economics, Johns Hopkins University.

Carrington, William, and Kenneth Troske. 1998. "Interfirm Segregation and the Black/White Wage Gap." Journal of Labor Economics 16 (2): 231-260.

Case, Anne, and Lawrence Katz. 1991. "The Company You Keep: The Effects of Family and Neighborhood on Disadvantaged Youth.” Working Paper, National Bureau of Economic Research.

Chay, Kenneth. 1995. "The Impact of Federal Civil Rights Policy on Black Economic Progress: Evidence from the Equal Opportunity Act of 1972." Mimeographed, Princeton University.

Cutler, David, and Edward Glaeser. 1997. “Are Ghettoes Good or Bad?” Quarterly Journal of Economics 112 (3): 827-872.

Falcon, Luis, and Edwin Melendez. 1997. "The Social Context of Job Searching for Racial Groups in Urban Centers.” Mimeographed, Northeastern University.

Farley, Reynolds, Harry Holzer, and Sheldon Danziger. 1998. Detroit Divided: Racial Inequality in Housing and Labor Markets. New York: Russell Sage Foundation. 
Fix, Michael, and Raymond Struyk, eds. 1994. Clear and Convincing Evidence: Measurement of Discrimination in America. Washington, DC: Urban Institute Press.

Freeman, Richard, and James Medoff. 1984. What Do Unions Do? New York: Basic Books.

Frey, William. 1995. "The New Geography of Population Shifts." In State of the Union: America in the 1990s, edited by R. Farley, New York: Russell Sage Foundation.

Fuchs, Victor. 1989. “Women's Quest for Economic Equality.” Journal of Economic Perspectives 3 (1): $25-41$.

Haar, Charles. 1996. Suburbs under Siege: Race, Space, and Audacious Judges. Princeton, NJ: Princeton University Press.

Harrison, Bennett, and Marcus Weiss. 1998. Workforce Development Networks. Thousand Oaks, CA: Sage Publications.

Hauser, Robert, and Hanam Samuel Phang. 1993. "Trends in High School Dropout among White, Black, and Hispanic Youth, 1973 to 1989.” Discussion Paper no. 1007-03, Institute for Research on Poverty, University of Wisconsin-Madison.

Hirsch, Barry, and David MacPherson. 1994. "Wages, Racial Composition and Quality Sorting in Labor Markets." Mimeographed, Florida State University.

Holzer, Harry J. 1987. "Informal Job Search and Black Youth Unemployment." American Economic Review 77 (2): 446-452.

Holzer, Harry J. 1996. What Employers Want: Job Prospects for Less-Educated Workers. New York: Russell Sage Foundation.

Holzer, Harry J. 1998. "Employer Hiring Decisions and Antidiscrimination Policy." In Generating Jobs: How to Increase Demand for Less-Educated Workers, edited by R. Freeman and P. Gottschalk, New York: Russell Sage Foundation.

Holzer, Harry J. Forthcoming. "Why Do Small Establishments Hire Fewer Blacks than Larger Ones?" Journal of Human Resources.

Holzer, Harry, and Keith Ihlanfeldt. 1996. "Spatial Factors and the Employment of Blacks at the Firm Level." New England Economic Review, May/June, pp. 65-82.

Holzer, Harry, and Keith Ihlanfeldt. Forthcoming. "Customer Discrimination and the Employment Outcomes of Minority Workers." Quarterly Journal of Economics.

Holzer, Harry, Keith Ihlanfeldt, and David Sjoquist. 1994. "Work, Search, and Travel among White and Black Youth." Journal of Urban Economics 35: 320-345.

Holzer, Harry, Lawrence Katz, and Alan Krueger. 1991. "Job Queues and Wages." Quarterly Journal of Economics 106: 739-768. 
Hughes, Mark, and Julie Sternberg. 1992. The New Metropolitan Reality: Where the Rubber Meets the Road in Antidiscrimination Policy. Washington, DC: Urban Institute.

Ihlanfeldt, Keith. 1997. "Information on the Spatial Distribution of Opportunities within Metropolitan Areas." Journal of Urban Economics 41: 218-242.

Ihlanfeldt, Keith. Forthcoming. "Is the Labor Market Tighter Outside the Ghetto?" Papers in Regional Science.

Jargowsky, Paul. 1997. Poverty and Place: Ghettos, Barrios, and the American City. New York: Russell Sage Foundation.

Kain, John. 1992. “The Spatial Mismatch Hypothesis Three Decades Later.” Housing Policy Debate 3: 371-462.

Katz, Lawrence, Jeffrey Kling, and Jeffrey Liebman. 1997. "Moving to Opportunity in Boston: Early Impacts of a Housing Mobility Program.” Mimeographed, Harvard University.

Kenney, Genevieve, and Douglas Wissoker. 1994. "An Analysis of the Correlates of Discrimination Facing Young Hispanic Job-Seekers.” American Economic Review 84 (4): 674-683.

Kirschenman, Joleen. 1991. "Gender within Race in the Labor Market." Mimeographed, University of Chicago.

Kirschenman, Joleen, and Katherine Neckerman. 1991. "We'd Love to Hire Them But ..." In The Urban Underclass, edited by C. Jencks and P. Peterson, Washington, DC: Brookings Institution.

Krueger, Alan, and Lawrence Summers. 1987. "Reflections on the Inter-Industry Wage Structure.” In Unemployment and the Structure of Labor Markets, edited by K. Lang and J. Leonard, New York: Basil Blackwell.

Lang, Kevin, and William Dickens. 1993. "Bilateral Search as an Explanation for Labor Market Segmentation and Other Anomalies." Working Paper, National Bureau of Economic Research.

Leonard, Jonathan. 1985. "Space, Time and Unemployment." Unpublished, University of California.

Leonard, Jonathan. 1990. "The Impact of Affirmative Action Regulation and Equal Employment Law on Black Employment.” Journal of Economic Perspectives 4 (4): 47-63.

Mare, Robert. 1995. "Changes in Educational Attainment and School Enrollment." In State of the Union: America in the 1990s, edited by R. Farley, New York: Russell Sage Foundation.

Mieszkowski, Peter, and Edwin Mills. 1993. "The Causes of Metropolitan Suburbanization." Journal of Economic Perspectives 7 (3): 135-147.

Raphael, Steven. 1998. "The Spatial Mismatch Hypothesis of Black Youth Joblessness: Evidence from the San Francisco Bay Area. Journal of Urban Economics 43(1): 79-111. 
Raphael, Steven, Michael Stoll, and Harry Holzer. 1998. "Are Suburban Firms More Likely to Discriminate against African Americans?” Discussion Paper no. 1160-98, Institute for Research on Poverty, University of Wisconsin-Madison.

Roberts, Brandon. 1998. Welfare-to-Work: Strategies to Assist the Private Sector Hire Welfare Recipients. Chevy Chase, MD: Brandon Roberts and Associates.

Rosenbaum, James, and Susan Popkin. 1991. "Employment and Earnings of Low-Income Blacks Who Move to Middle-Class Suburbs." In The Urban Underclass, edited by C. Jencks and P. Peterson, Washington, DC: Brookings Institution.

Tigges, Leann, Irene Browne, and Julie Press. 1997. "Multiple Jeopardy in Multiple Labor Markets: The Intersection of Gender and Race/Ethnicity in Four Cities." Mimeographed, University of Wisconsin.

Waldinger, Roger. 1996. Still the Promised City? African-Americans and New Immigrants in Postindustrial New York. Cambridge, MA: Harvard University Press.

Yinger, John. 1995. Closed Doors, Opportunities Lost: The Continuing Costs of Housing Discrimination. New York: Russell Sage Foundation.

Zax, Jeffrey. 1991. "Compensation for Commutes in Labor and Housing Markets." Journal of Urban Economics 30: 192-207. 